\title{
Öğrenme Stilleri Modellerinin İncelenmesi
}

\author{
Investigation of Learning Styles Model
}

Ayşe BAYIRLI*, Meliha Aslam ORKUN ${ }^{+}$\& Sibel BAYIRLI ${ }^{\ddagger}$

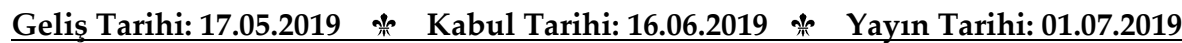

\section{Özet}

Öğrencilerin öğrenme stil ve stratejilerini bilmesi, öğrenme güçlüklerini yenme ve bağımsız öğrenme becerilerini desteklemesi açısından önemlidir. Çünkü kendi öğrenme stilinin farkında olan öğrenci öğrenmek için neye ihtiyacı olduğunu, öğrenmek için nasıl bir yol izlemesi gerektiğini bilir. Birey kendi öğrenme stilini bildiğinde daha kolay ve çabuk öğrenebilir; karşılaştığı problemlerde daha hızlı çözüm üretebilir; kendine güven duygusu artar, kaygı düzeyi azalır; derslere ve okula karşı olumlu tutum geliştirebilir. Bu çalışmada öğrenmeyi öğrenme sürecinde önemli olan öğrenme stilleri modellerinin incelenmesi amaçlanmıştır. Bu kapsamda çalışmada Kolb'un yaşantısal öğrenme stili modeli, Mccarthy öğrenme stili modeli, Carl Jung'un psikolojik tipler kuramı, Myers-Briggs öğrenme stili modeli, Gregorc'un öğrenme stili modeli, Honey ve Mumford'un öğrenme stili modeli ve görsel, işitsel, kinestetik/devinimsel öğrenme stilleri incelenmiştir. Çalışmada nitel araştırma yöntemlerinden, doküman incelemesi yöntemi kullanılmıştır. Veriler toplanırken, öğrenme stilleri ile ilgili kitap, dergi, makale, köşe yazısı, resmi belge ve rapor gibi basılı ve internet kaynaklarından yararlanılmıştır. Elde edilen veriler temalar halinde sunulan başlıklar altında raporlanmıştır.

Anahtar kelimeler: Öğrenme stili, öğrenme stili modelleri, öğrenmeyi öğrenme.

\section{Abstract}

It is important for students to know their learning styles and strategies, to overcome learning difficulties and to support independent learning skills. Because the student who is aware of his own learning style knows what he needs to learn, how to follow the path to learn. The individual can learn more easily and quickly when he knows the style of learning; produce faster solutions to the problems they face; self-confidence increases, anxiety level decreases; develop positive attitudes towards classes and school. In this study, it is aimed to investigate learning styles models that are important in the learning process. In this study, Kolb's experiential learning style model, Mccarthy learning style model, Carl Jung's theory of psychological types, Myers-Briggs learning style model, Gregorc's learning style model, Honey and Mumford's learning style model and visual, auditory, kinesthetic I dynamic learning styles were investigated. In the study, document analysis method was used among

\footnotetext{
* Öğretmen, Kıbrıs Millî Eğitim Bakanlı̆̆ı, fatosbyrbayirli@gmail.com

+ Öğretmen, Kıbrıs Millî Eğitim Bakanlığı, meliha.83aslam@gmail.com

‡ Öğretmen, Kıbrıs Millı̂ Eğitim Bakanlığı, alibahadir@gmail.com
} 
qualitative research methods. While collecting the data, books, magazines, articles, columns, print and internet resources such as official documents and reports about learning styles models were used. The data obtained were reported under the headings presented as themes.

Keywords: Learning style, learning style models, learning to learn.

\section{Giriş}

İnsanlar öğrenme yetenekleri açısından benzerlikler taşısa da öğrenme tarzları farklıdır. Herkes öğrenebilir ama herkes aynı şekilde öğrenemez. Kişiler arası bu farklılıkların olması herkese uyan bir öğrenme stilinin olmamasından kaynaklanır. $\mathrm{Bu}$ farklılıklar dikkate alınmadan planlanan eğitim faaliyetlerinden bütün öğrenciler eşit şekilde faydalanamaz. Öğrencilerin hangi öğrenme stillerine sahip olduğunun bilinmesi eğitimde uygun yöntem, strateji, teknik ve materyal seçimine yardımcı olur (Ergün, 1999). Alanyazın incelendiğinde öğrenme stillerinin birçok araştırmacı tarafından yorumlandığı görülmektedir. Öğrenme stilleri Demirel (2010) tarafından kalıcı kişilik örüntüleri olarak tanımlanmıştır. Demirel'e göre bu kalıcı kişilik örüntüleri kişi ile çevre arasında bir etkileşim ürünüdür. Felder ve Henriques'e (1995) göre öğrenme stilleri, bireylerin bilgiyi alma, tutma ve işleme sürecindeki karakteristik bağımlılığı ve tercihleridir. Erden ve Altun'a (2006, s. 21) göre bireyin fiziksel ve duyuşsal ihtiyaçlarını etkileyen, çevresel ve algısal tercihlerinin etken olduğu bir olgu iken, Durukan'a (2013) göre öğrenme stilleri kavramı "bireyin doğuştan getirdiği; yeni bir bilgiyi öğrenirken, hatırlarken veya kullanırken kendine özgü kullandığı yol ve onun başarısını etkileyen karakteristik özelliği" olarak tanımlanmaktadır. Tanımlardan da anlaşılacağı üzere bireysel bir farklılık olarak ortaya çıkan öğrenme stilleri nitel bir değişkendir, fazla sayısallaştıılamaz ve kolayca değişim göstermez. Ayıca, öğrenme stillerinin genel olarak öğrenmeyi etkilediği ve bazı öğrenme stillerinin belirli türdeki öğrenme ürünlerinin kazanılmasını kolaylaştırdığı belirtilmektedir (Oral ve Avanoğlu, 2011).

Oral ve Avanoğlu'na göre bireyin öğrenme stilinin belirlenmesi;

- bireylerin öğrenme döngüsündeki güçlü ve zayıf yönlerinin bilinmesine,

- zayıf yönlerinin geliştirilmesi için önlemler alınmasına,

- birlikte çalışmaya en uygun bireylerin bir araya getirilmesine,

- sinıflardaki çeşitliliğin gözetilmesine,

- öğrencilerin başarı, ilgi ve motivasyonlarını olumlu yönde etkileyecek öğrenme ortamlarının ve eğitim programlarının hazırlanmasına olanak sağlar.

Her öğrenci, bilgiyi alma ve işleme sürecinde, tercih ettiği yol ve yöntemler farklıdır. Diğer bir deyişle öğrenme sürecindeki her öğrenci, farklı öğrenme stillerine sahiptir. Bazı öğrenciler olgulara ve verilere odaklanırken bazı öğrenciler kuram ve 
matematikte daha rahattırlar. Bazı öğrenciler resimler, diyagramlar, şemalar gibi görsel unsurlara eğilim gösterirken bazıları da sözel formları tercih eder. Bazı öğrenciler de aktif ve uygulamalı öğrenmeyi tercih ederken bazıları da daha kişisel ve kendi duyguları 1şı̆̆ında öğrenmeyi tercih eder (Felder, 1996). Tüm bu öğrenme sürecindeki bireysel farklılıkların anlaşılmasıyla öğrenme stilleri kavramı ortaya çıkmış ve araştırmacıları bu alana yönlendirmiştir (Can, 2011).

Öğrenme stili kavramı ilk kez Dunn tarafından ortaya atılmış ve birçok araştırmacı tarafından öğrenme stilleri üzerine modeller kurulmuştur (Çakır ve diğerleri, 2013). Kolb'un öğrenme stili, McCarthy'nin öğrenme stili, Jung'un öğrenme stili, Myers-Briggs'in öğrenme stili, Gregorc'un öğrenme stili ve Honey ve Mumford'ın öğrenme stili ve görsel, işitsel, kinestetik/devinimsel öğrenme stilleri modelleri bunların en önemlilerine örnek teşkil etmektedir. Dolayısıyla bu çalışmada söz konusu modellerin genel hatlarıyla incelenmesi amaçlanmıştır.

\section{Yöntem}

Çalışmada nitel araştırma yöntemlerinden, doküman incelemesi yöntemi kullanılmıştır. Doküman incelemesi, araştırılması hedeflenen olgu veya olgular hakkında bilgi içeren yazılı materyallerin analizini kapsar. Nitel araştırmada doküman incelemesi tek başına bir veri toplama yöntemi olabileceği gibi diğer veri toplama yöntemleri ile birlikte de kullanılabilir (Yıldırım ve Şimşek, s. 187). Veriler toplanırken, öğrenme stilleri ile ilgili kitap, dergi, makale, köşe yazısı, resmi belge ve rapor gibi basılı ve internet kaynaklarından yararlanılmıştır. Elde edilen veriler temalar halinde sunulan başlıklar altında raporlaştırılmıştır.

\section{Öğrenme Stilleri Modelleri}

\section{Kolb’un yaşantısal öğrenme stili modeli}

Bireyin farklı öğrenme biçimlerini bir arada kullanabilmesi, kişinin etrafındaki olayları gözlemlemesi, bunları kuramlarla bütünleştirmesi, hipotezler kurup test etmesi ve yaşantılar seçmesine yol açmaktadır (Kolb, 1984; akt. Demirel, 2010, s.153). Kolb'un Öğrenme Stili Modeli, onun yaşantısal öğrenme kuramına dayanmaktadır. Kolb'un Öğrenme Stili Modeli somut yaşantı, soyut kavramsallaştırma, aktif yaşantı ve yansitıcı gözlem olmak üzere dört öğrenme boyutunu içermektedir. Bu dört öğrenme boyutunun bileşenleri öğrenme stillerini belirlemektedir (Kaf Hasırc1, 2006). Her bir öğrenme biçimini simgeleyen öğrenme yolları birbirinden farklıdır. Bunlar sırasıyla; somut yaşantı için "hissederek", yansıtıcı gözlem için "izleyerek", soyut kavramsallaştırma için "düşünerek" ve aktif yaşantı için yaparak öğrenmedir (Aşkar ve Akkoyunlu, 1993). 


\section{Somut yaşantı}

$\mathrm{Bu}$ öğrenme aşamasında öğrenen, sistematik olarak yaklaşmaktan çok duygulara dayalı bir yaklaşımı tercih eder. Kolb'a (1984) bu öğrenme biçimine sahip kişilerin diğer kişilerle birlikte olmaktan mutlu olduklarını; gerçek yaşantıdan zevk aldıklarını, yeni görüş ve düşüncelere açık ve incelemeye istekli olduklarını, genelde sezgilere dayalı karar verme ve yapısal olmayan durumlarda başarılı olduklarını vurgulamıştır (akt. Demirel, 2010).

\section{Yansıtıcı gözlem}

Bu öğrenme aşaması düşünce ve olayları dikkatlice gözlemleyerek farklı görüş açılarından değerlendirme süreci üzerine odaklanmıştır. Bu tarz öğrenenler kendi görüşlerini oluşturmada kişisel fikir ve hislerine dayanırlar. Başka bir ifadeyle, bu aşamadaki insanlar, izleyerek ve dinleyerek öğrenirler ve karar vermeden önce dikkatlice gözlem yaparlar (Oral ve Avanoğlu, 2011)

\section{Soyut kavramsallaştırma}

$\mathrm{Bu}$ öğrenme biçimindeki öğreniciler öğrenirken, problem ya da durumları anlamak için hislerden ziyade mantık ve fikirleri kullanır. Tipik olarak bu öğrenen, problem çözmek için kuramlar geliştirir ve sistematik planlamayı tercih eder. Bu gruptaki bireyler düşünce ve olayların mantıksal analizini yaptıktan sonra hareket ederler (Aşkar ve Akkoyunlu, 1993).

\section{Aktif yaşantı}

$\mathrm{Bu}$ öğrenme biçiminde bireyler çevrelerini etkileme ve durumlarını değiştirme özelliğine sahiptir. Bu öğrenme biçiminde izlemek ve gözlemlemekten çok pratik uygulamalar yapma, işe yarayanı benimseyip diğerlerini reddetme söz konusudur. $\mathrm{Bu}$ öğrenme biçimini benimseyen bireylerin çevreleri üzerinde etkili, başladıkları işi tamamlama ve hedeflerine ulaşabilmek için risk alma konusunda duyarlı ve başarılı oldukları belirtilmektedir (Demirel, 2010).

Tablo 1. Kolb’ un Öğrenme Stilleri, Öğrenme Biçimleri ve Bunlarm Öğrenme Yollarn Arasındaki İlişki

\begin{tabular}{|c|c|c|c|c|}
\hline \multirow{2}{*}{$\begin{array}{l}\text { Öğrenme Stili } \\
\text { Ayrıştıran }\end{array}$} & \multicolumn{2}{|c|}{ Öğrenme Biçimleri } & \multicolumn{2}{|c|}{ Öğrenme Yolları } \\
\hline & Aktif yaşantı & $\begin{array}{l}\text { Soyut } \\
\text { kavramsallaştırma }\end{array}$ & Yaparak & Düşünerek \\
\hline Özümseyen & $\begin{array}{l}\text { Soyut } \\
\text { kavramsallaştırma }\end{array}$ & Yansitıcı gözlem & Düşünerek & İzleyerek \\
\hline Değiştiren & Yansitıcı gözlem & Somut yaşantı & İzleyerek & Hissederek \\
\hline Yerleştiren & Somut yaşantı & Aktif yaşantı & Hissederek & Yaparak \\
\hline
\end{tabular}

( Veznedaroğlu ve Özgür (2005). 
Yaşantısal öğrenme kuramına göre öğrenme bir döngüdür ve birey için zaman zaman bu dört öğrenme biçiminden biri öncelik kazanır. Kolb'a göre, bireyin öğrenme stilini belirleyen tek bir biçim yoktur. Her bireyin öğrenme stili bu dört temel biçimin bileşenidir. Bunlar; ayrıştıran, özümseyen, değiştire ve yerleştiren öğrenme stilleridir. Öğrenme stillerinin bilinmesi bireylerin meslek seçimine, problemlere yaklaşımına ve amaçlarını nasıl belirleyeceklerine yardımcı olur (Aşkar ve Akkoyunlu, 1993). Kolb'un Öğrenme stilleri aşağıda kısaca verilmiştir:

\section{Ayrıştıran}

Soyut kavramsallaştırma ve aktif yaşantı öğrenme biçimlerinin bileşiminden oluşur. Problem çözme, karar verme, mantıksal analiz ve sistematik planlama belirgin özellikleridir. Problem çözerken sistemli olarak planlama yaparlar. Yaparak öğrenme bunlar için önemlidir. Öğrenilen materyali uygulamak için fırsatlara ihtiyaç duyarlar. Öğrenme sürecinde bütünü görmek, bütünden parçaya gitmek ihtiyacındadırlar.

\section{Özümseyen}

Soyut kavramsallaştırma ve yansıtıcı gözlem öğrenme biçimlerinin kombinasyonlarından oluşur. Kavramsal modeller yaratmak en belirgin özelliklerdir. Öğrenirken soyut kavramlar ve fikirler üzerinde odaklanırlar. Bilgiyi işlemek için fırsatlara ihtiyaç duyarlar. Genellikle matematik ve temel bilimlerde uzmanlaşırlar.

Tablo 2. Kolb'un Öğrenme Biçimleri ve Yardımoı Sınıf Etkinlikleri

\begin{tabular}{ll}
\hline Öğrenme Biçimi & Sınıf Ekinlikleri \\
\hline Somut yaşantı & $\begin{array}{l}\text { Açık uçlu problemler, öğrenci sunumları, tasarım projeleri, } \\
\text { simülasyonlar }\end{array}$ \\
Yansıtıcı gözlem & $\begin{array}{l}\text { Motivasyonel hikayeler, grup tartışmaları, grup projeleri, } \\
\text { subjektif testler, alan gezileri }\end{array}$ \\
Soyut kavramsallaştırma & $\begin{array}{l}\text { Dersler, ders kitabını okuma, öğretici tarafından yapılan } \\
\text { gösteriler, bağımsız araştırmalar, objektif sınavlar }\end{array}$ \\
Aktif deneyim & Ev ödevi problemleri, bilgisayar simülasyonları, alan gezileri, \\
& bireysel raporlar, gösteriler \\
\hline
\end{tabular}

(Oral ve Avanoğlu (2011)

\section{Değgiştiren}

Somut yaşantı ve yansıtıcı gözlem öğrenme biçimlerini kapsar. Düşünme yeteneği, değer ve anlamların farkında olmaları en belirgin özellikleridir. Somut durumları birçok açıdan gözden geçirirler ve ilişkileri anlamlı bir şekilde örgütlerler. Öğrenme durumunda sabırlı, nesnel, dikkatli yargıda bulunurlar ancak, eylemde bulunmazlar. Düşünceleri biçimlendirirken kendi duygu ve düşüncelerini ön planda tutarlar. Genellikle sosyal alanlarda uzmanlaşırlar. 


\section{Yerleştiren}

Somut yaşantı ve aktif yaşantı öğrenme biçimini kapsamaktadır. Planlama yapma, kararları yürütme ve yeni deneyimler içinde yer alma belli başlı özellikleridir. Öğrenme ortamında açık fikirlidirler ve değişimlere kolay uyum sağlarlar. Yaparak ve hissederek öğrenme söz konusudur. Öğrenilen kavramları yeni problemlere uygulamak için fırsatlara ihtiyaç duyarlar, keşfetmeye yönelik etkinliklere ihtiyaç duyarlar (Aşkar ve Akkoyunlu, 1993; Oral ve Avanoğlu, 2011; Veznedaroğlu ve Özgür, 2005).

\section{McCarthy öğrenme stili modeli}

McCarthy'e göre öğrenme yeni şeyleri kavramak ve bunlara yönelik tepkiler gerçekleştirmektir. McCarthy öğrenme stilini, bireylerin bilgiyi algılama ve işleme yeteneklerini kullanmadaki tercihi şeklinde tanımlamıştır. McCarthy öğrenme stili modelini Kolb'un öğrenme stili modelini temel alarak oluşturmuştur (Oral ve Avanoğlu, 2011). McCarthy öğrenme stillerini dört gruba ayırmaktadır. Bunlar; buluşçu, analitik, sağduyulu ve dinamik öğrenenlerdir (McCarthy, 2000). Bu öğrenme stiline sahip bireylerin temel özellikleri kısaca aşağıda verilmiştir (McCarthy, 2000):

\section{Tip 1: Buluşçu öğrenenler}

Bu tip öğrenenler, daha çok, bireysel olarak anlamlandırmayı benimserler. Yeni bilgilerin öğrenilmesinde ve anlamlandırılmasında bireysel düşünce yapıları ile ilişkilerini düşünürler. Grup çalışmalarını, disiplinler arası çalışmaları ve beyin fırtınası uygulamalarını daha çok tercih ederler.

\section{Tip 2: Analitik öğrenenler}

$\mathrm{Bu}$ tip öğrenenler, temel bilgi kuramlarını kendi anlamalarını geliştirmek için çok iyi kullanır ve öğrenirler. Direk anlatım, veri analizi, bağımsız araştırma yapmayı çok severler. Alanında uzman kişiler ile bilgi paylaşımına önem verirler.

\section{Tip 3: Să̆duyulu öğrenenler}

$\mathrm{Bu}$ tipte öğrenenler ise, çoğunlukla bir bilgiyi kabul etmeden önce denemek, yanılmak ve görmek isterler. Öğrenme sürecinde deneysel çalışmalara çok önem verirler.

\section{Tip 4: Dinamik öğrenenler}

$\mathrm{Bu}$ tip öğrenenler de bireyselleştirilmiş keşif, araştırma etkinliklerini tercih ederler. Kendi önsezilerini kullanmada oldukça iyidirler ve bağımsız çalışmalarda başarılı ve aktif roller alabilirler. 


\section{Carl Jung'un psikolojik tipler kuramı}

Jung, temelde iki insan tipi üzerinde durmuştur: Dişadönük ve içedönük. Bu insan tiplerinin temel özellikleri Veznedaroğlu ve Özgür (2005) aşağıdaki gibi belirtilmiştir:

Tablo 3. Jung'un Karakter Tipleri

\begin{tabular}{|c|c|}
\hline DIȘADÖNÜK & İCEDÖNÜK \\
\hline 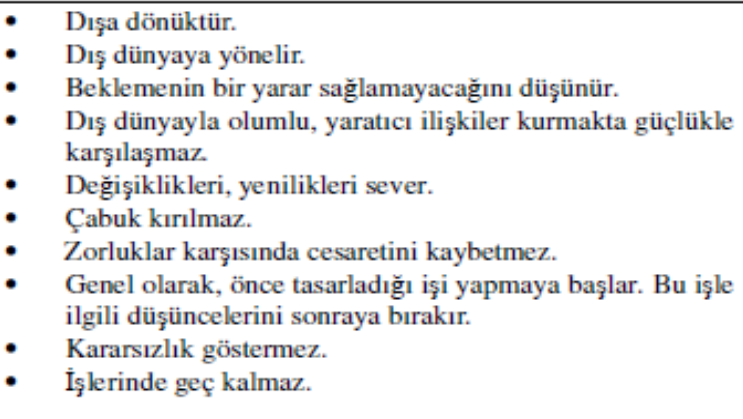 & $\begin{array}{l}\text { - } \quad \text { Kendisine dönüktür. } \\
\text { - } \quad \text { Anılar, hayaller dünyasında yaşar. } \\
\text { - } \quad \text { Bir şey yapmaya başlamadan önce uzun uzun düşünür. } \\
\text { Sakacağı işin sonuçlarını kendi kendine tartı̧ır, } \\
\text { Bakıncalı yanların| olup olmadığını anlamaya çalışır. } \\
\text { Bu nedenle karar vermekte zorlanır, zaman kaybeder, } \\
\text { işin gecikmesine neden olur. } \\
\text { Utangaçtur. } \\
\text { - Kendisine, dolayısıyla başkasına güvenmez.bunun } \\
\text { sonucu olarak, başkasıyla kurduğu, ama zorlukla } \\
\text { kurduğu ilişkilerinde kuşku duymaktan kendini } \\
\text { alamaz. } \\
\text { Cevresine uymakta güclük ceker. }\end{array}$ \\
\hline
\end{tabular}

Felder, (1996) Jung'un bu kuramını şöyle açıklamaktadır: eğer kişi daha çok dış dünyayla ilgileniyorsa dişadönük, iç dünyayla ilgileniyorsa içedönük olarak adlandırılır. Dışadönük kişi, aktif ve kendine güvenli, diğer insanlarla zaman geçirmekten hoşlanan ve girişimci kişidir. İçedönük kişi, diğer insanlarla zaman geçirmekten pek hoşlanmayan, düşüncelere ve hislere odaklanan kişidir.

İnsanlar algılama sürecindeki eğilimlerine göre ikiye ayrılabilir: Algısallar ve sezgiseller. Algısallar gözlem ve deneylerden elde edilen gerçek, somut, sayılabilir veriler, olguları tercih ederler. Pratiktirler, süreçlere ve detaylara odaklanırlar. Sezgiseller ise içe bakış ve hayal gücü aracılığıyla anlamlara ve olasılıklara odaklanırlar. Kavramları, ilişkileri tercih ederler. Jung'un tipolojisine göre insanlar karar verme ve değerlendirme süreçlerindeki eğilimlerine göre ikiye ayrılırlar; düşünürler ve hissedenler.

Düşünürler objektif, mantık ve analize dayanan kararlar verme eğilimi gösterirler. Şüphecidirler, kurallara dayalı karar verirler. Hissedenler ise değerlere ve diğerlerinin üzerindeki etkiye bağlı olarak öznel kararlar verme eğilimindedirler. Takdir edicidirler, kişisel ve insani koşulları göz önünde bulundururlar. Jung'un kişilik tipleri modeli, öğrenme stilleri alanındaki birçok modeli özellikle de dışadönük-içedönük ve algısal-sezgisel alanları yoğun bir şekilde etkilemiştir (Veznedaroğlu ve Özgür, 2005).

\section{Myers-Briggs öğrenme stili modeli}

Myers-Briggs, Carl Jung'un psikolojik tiplerinden esinlenerek bir siniflama yapmışlardır. Myers-Briggs'e göre öğrenciler aşağıdaki tiplerden birinde yer alabilirler. 


\section{Dışadönükler-içedönükler}

Dışadönük öğrenciler konuları deneme yanılma yoluyla öğrenirler. Çevrelerindeki bireylere odaklanırlar. İçedönükler ise kendi iç dünyaları çerçevesinde düşünürler.

\section{Duygusallar-sezgiseller}

Duygusallar pratik uygulamalar yaparlar, ayrıntı, yöntemler ve işlemlere odaklanmayı severler. Sezgiseller hayal gücü gelişmiş, yaratıcı, kavram eğilimlidirler. Anlamalara ve olasılıklara odaklanırlar.

\section{Düşünürler-hisliler}

Düşünürler şüphecidirler, mantıksal ve kurallara kararları yeğlerler. Hisliler, değerlere önem verirler, kişisel ve insancıl düşüncelere dayalı karar verme eğilimindedirler.

\section{Yargılayıcılar-algılayıcılar}

Yargılayıcılar bir gündeme göre davranma eğilimindedirler. Konuyla ilgili olmayan bilgileri bile araştırma peşindedirler. Algılayıcılar ise değişen durumlara kolaylıkla uyum sağlarlar. Bir konu hakkında daha fazla veriye ihtiyaç duyarlar.

Myers-Briggs'e göre bir öğrenci dışadönük, duygusal, düşünür ve algılayıcı iken bir diğeri içedönük, sezgisel, hissi ve yargılayıcı psikolojik özelliklerine sahip olabilir (Oral ve Avanoğlu, 2011).

\section{Gregorc'un öğrenme stili modeli}

Gregorc'a göre kişinin öğrenmesinde ve öğrenme stillerinde algılama yeteneği çok önemlidir. Kişiler algılama yeteneklerine göre somut ve soyut algılayanlar, algıladıkları verileri düzenleme yeteneklerine göre ardışık ve random olmak üzere ikiye ayrılırlar. Kişilerin algılama yeteneklerine göre de oluşturdukları öğrenme durumları onların öğrenme stillerini oluşturur. Buna göre Gregorc Öğrenme Stili Modeli'nde; Somut Ardışık, Soyut Ardışık, Somut Random, Soyut Random öğrenme stilleri olmak üzere toplam dört öğrenme stili bulunmaktadır. Belirtilen dört öğrenme stiline sahip bireylerin kısaca şu özellikleri taşıdıkları belirtilmektedir (Gregorc, 1984; akt. Ekici, 2013):

Somut Ardışık öğrenme stiline sahip bireylerin özellikleri: Yaparak yaşayarak öğrenmeyi severler, bilgilerin kendilerine adım adım ve basitten karmaşığa doğru verilmesini isterler, yaptıkları çalışmaların parçalarından çok bütünü önem taşır, beş duyu organları son derece gelişmiştir. Somut materyallerle öğrenmeyi tercih ederler.

Soyut Ardışık öğrenme stiline sahip bireylerin özellikleri: Öncelikle öğrenecekleri konu ile ilgili olarak zihinlerinde boş bir çerçeve yapı oluştururlar. Kendilerine düzenli olarak verilen bilgilerden uygun olanları alırlar ve zihinlerinde 
oluşturdukları çerçevenin içine yerleştirerek konunun bütünü hakkında bir sonuca ulaşırlar. Bu kişiler için bir şekil/sembol yüzlerce kelimeden değerlidir.

Somut Random öğrenme stiline sahip bireylerin özellikleri: Problem çözme konusunda üstün yetenekleri vardır. Gerçek problemlerle ilgilenirler, yeni kavramlar ve bilgiler elde etmeye çalışan araştırmacı bir kişilikleri vardır. Problem çözerken bilgilerin sistematik bir düzen içinde verilmesine ihtiyaç duymazlar.

Soyut Random öğrenme stiline sahip bireylerin özellikleri: Olayları ve kavramları düzensiz karışık bir şekilde algılarlar, onlar için öğrenilecek bilgilerde bir düzenin olmasına gerek yoktur. Bu yüzden çoklu duyumsal deneyimlerin bulunduğu ortamlarda öğrenmeyi tercih etmektedirler. Duygu ve düşüncelerini açıkça ifade etmekte başarılıdırlar.

\section{Honey ve Mumford'ın öğrenme stili modeli}

Peter Honey ve Alan Mumford, Kolb'un öğrenme döngüsünden yararlanarak bir öğrenme stili modeli geliştirmişlerdir. Öğrenme stillerini öğrenenlerin yaptıkları tercihe göre dört aşamada açıklamışlardır (Oral ve Avanoğlu, 2011). Bu öğrenme stillerine sahip bireylerin özellikleri ise şöyledir:

\section{Eylemciler}

Açık fikirlidirler ve esnektirler. Yeni deneyimlerden hoşlanan bireyler olan eylemciler, sezgileriyle karar vermeye eğilimlidirler, ancak önceden yapılandırılmış kalıplardan hoşlanmazlar. Göreceli olarak kısa görevler neticesinde öğrenirler. Bu görevler iş ya da dersler hakkında yönetsel etkinlikler olabilir: iş oyunları veya rekabetçi grup çalışmaları gibi. Dinleme ya da okuma gibi pasif etkinlikler içerisinde az öğrenirler.

\section{Kuramcilar}

Akılcı, tarafsız ve dikey düşünürler. Fikirlere, mantığa ve sistematik planlamaya odaklanırlar, ancak sezgiler ve duygular konusunda güvensizdirler. Öğrendiklerini bir sistem, kavram, model ya da kuram olarak tekrarlayabileceklerse iyi öğrenirler. Gerçek olmayan, ancak yapılandırılmış konularla da ilgilenebilir ve bu yolla da öğrenebilirler. Bir taslak etrafında örgütlenmemiş bilgileri öğrenmekte zorlanırlar.

\section{Faydacilar/Pragmatistler}

Uygulamada olanların değerini test etmeyi severler. Pratik hareket etmekten, gerçekçi yaklaşımlardan, grup çalışmalarından, tartışmaktan ve risk almaktan hoşlanırlar, ancak derin düşünmekten kaçınmaya eğilimlidirler. Konu ve işteki sorun ve/veya fırsat arasında görünür bir ilişki varsa öğrenirler. İş ortamına hemen uygulayabilecekleri teknik ve süreçleri öğrenmek isterler. İşlerine gelmeyen öğrenilmesi zor olan bilgilerden uzaklaşırlar. 


\section{Yansitıcilar}

Oldukça dikkatlidirler. Yöntem ve yönergeleri uygulamayı benimserler risk almayı sevmezler. Süreçleri gözlemleyip, açılarlar, sonuçları öngörmeye, anlamı açıklamaya ve anlamaya çalışırlar. Geride durup dinleyerek, gözlem yapabilecekleri etkinliklerden daha çok öğrenirler. Bilgi toplamaktan ve topladıkları bilgi hakkında düşünmeye fırsat verilmesinden hoşlanırlar. Planlama fırsatının verilmediği, çalışmalardan esnasında çok az öğrenirler (Tepehan, 2004).

\section{Görsel, işitsel, kinestetik/devinimsel öğrenme stilleri}

Eğitim literatüründe her ne kadar öğrenme stilleri farklı şekillerde sınıflandırılsa da bunları üç ana grupta toplamak mümkündür. Böyle bir gruplama, farklı öğrenme stillerine sahip olan öğrenciler için uygun öğrenme-öğretme ortamlarını hazırlamada öğretmenlerin işini kolaylaştırmada yardımcı olacaktır (Oral ve Avanoğlu, 2011).

\section{Görsel Öğrenme Stili}

Görsel öğrenme stilini kullanan bireyler bilginin görsel veya sunulduğunda daha iyi öğrenirler. Bu nedenle öğretmenlerin sınıf içi uygulamalarda görsel araç ve gereçlere yer vermesi önem kazanmaktadır. Bu tarz öğrenenler için görsel resim, bülten tahtası, fotoğraflar, bilgisayar ve projeksiyon gibi teknolojik cihazlar en iyi uyarıcılardır. Görselciler, daha çok yazılı tip ödevleri tercih etmektedirler (Demirel, 2010).

\section{İsitsel Öğrenme Stili}

İşitme yoluyla öğrenenler, bilgi sözel olarak sunulduğunda daha iyi öğrenirler. Kendi kendine konuşma ve diğerlerini dinleme yoluyla bilgiyi daha çabuk özümserler. Sınıfta dersi dinleme ve tartışmalara katılarak öğrenmeyi tercih ederler (Oral ve Avanoğlu, 2011).

\section{Kinestetik/Devinimsel Öğrenme Stili}

Kinestetik/devinimsel öğrenenler daha çok dokunarak ve dokunduklarını hissederek öğrenmeyi tercih ederler. $\mathrm{Bu}$ nedenle öğretmenlerin sinıf içi uygulamalarda öğrencilerin dokunabilecekleri somut araçları ve üç boyutlu öğretim materyallerini kullanmaları önemli görülmektedir. Öğrencilerden üç boyutlu öğretim materyallerini kullanarak plan hazırlamaları, gösteri yapmaları, deney hazırlamaları, rapor yazmaları ve değerlendirme yapmaları istenir (Demirel, 2010). 


\section{Sonuç -Tartışma}

Öğrenme stilleri Öğrenme sürecinde başarıya etki eden önemli bireysel farklılıklardan biridir. Senemoğlu (2013) öğrenme stillerinin öğrenme stratejileri gibi öğrencilerin kendi kendilerine öğrenmelerini sağlayan işlemler olduğunu ve bu işlemleri bilen öğrencilerin stratejik ve bağımsız öğrenenler olduklarını söylemektedir. Gerek öğrenme stilleri gerekse öğrenme stratejileri kavramı bireyin öğrenme sürecinde hangi yollarla bilgiyi aldığına, işlediğine ve hatırladığına dikkat çekmektedir. Birey kendi öğrenme stilini bildiğinde daha kolay ve çabuk öğrenebilir; karşılaştığı problemlerde daha hızlı çözüm üretebilir; kendine güven duygusu artar, kaygı düzeyi azalır; derslere ve okula karşı olumlu tutum geliştirebilir (Durukan, 2013). Son yıllardaki dikkat çeken araştırma konuları arasında yer alan öğrenme stratejileri, öğrenme stilleri ve kişilikle yakından ilişkilidir. Bireylerin yaşantılarını şekillendiren ve yaşantılar tarafından şekillenen kişilik, bilgi edinme, bilgiyi işleme ve bilgiyi kullanma süreçlerinde önemli bir rol görür (Dinçer, 2007). Öğrenme stratejileri uyaranları algılama, bilgileri kısa ve uzun süreli belleğe transfer etme ve bilgileri uzun süreli bellekte işleme süreçlerini kapsamaktadır (Numanoğlu ve Şen, 2007).

Öğrenenlerin öğrenme stratejilerini kullanabilme becerisi kendi öğrenme stillerinin farkında olmalarına bağlıdır (Arsal ve Özen, 2007). Çünkü kendi öğrenme stilinin farkında olan öğrenci öğrenmek için neye ihtiyacı olduğunu, öğrenmek için nasıl bir yol izlemesi gerektiğini bilir. Bu sadece öğrencinin bilmesi gereken bir husus değildir. Etkili öğrenme ortamlarının hazırlanmasında öğretmenlere büyük görevler düşmektedir (Yenen ve Dursun, 2018). Dolayısıyla öğretmenlerin öğrencilerin öğrenme stillerini göz önünde bulundurmaları ve onlara yol gösterici olmaları gerekmektedir. Güven (2004) de öğrencilerin öğrenme stil ve stratejilerini bilmesi, öğrenme güçlüklerini yenme ve bağımsız öğrenme becerilerini desteklemesi açısından önemli olduğunu vurgulamaktadır. Öğrenme stili ile bağdaşmayan ya da çok az uyuşan bir alanda öğrenim gören kişinin güven ve başarısında, sonuçta da kaygı düzeyinde değişiklikler olabilir.

Öğrenme stili bireyin, öğrenme sürecini denetim altına almasını, böylece öğrenme sorumluluğu üstlenebilmesini sağlar. Bu yolla birey, sürekli değişen ve artan bilgiyi yardım beklemeden elde edebilir (Güven, 2004). Kendi öğrenme stiline uygun öğrenme stratejilerini belirleyebilen öğrenci öğrenmeyi de öğrenmiş olur. Dolayısıyla, öğrenmeyi öğrenme sürecinin öğrenme stilleri ile yakından ilişkili olduğu, bu nedenle de öğrenme stili modellerinin öğrencilerin kendi öğrenmelerini düzenleyebilmeleri bakımından göz önünde bulundurulması unutulmamalıdır. 


\section{Kaynaklar}

Arsal, Z. \& Özen, R. (2007). Sınıf öğretmeni adaylarının öğrenme stratejileri ve öğrenme biçimi tercihlerinin incelenmesi. AİBய̈, Ĕ̆itim Fakültesi Dergisi, 7(2), 151-164.

Aşkar, P. \& Akkoyunlu, B. (1993). Kolb öğrenme sitili envanteri. Eğitim ve Bilim, 87, 37-47.

Can, Ş. (2011). Sınıf öğretmeni adaylarının öğrenme stilleri ile bazı değişkenler arasındaki ilişkinin araştırılması. Hacettepe Üniversitesi Ĕ̆itim Fakültesi Dergisi, 41, 70-82.

Çakır, Ö., Özdemir, F. B., Alkan, G. D. \& Ünal, K. (2013). Eğitim fakültesi öğrencilerinin öğrenme stil ve stratejilerinin çeşitli değişkenler açısından incelenmesi (Mersin Üniversitesi Örneği). Mersin Üniversitesi Eğitim Fakültesi Dergisi, 9(3), 56-76.

Dinçer, T. (2007). Anadolu Lisesi Öğrencilerinin Öğrenme Stilleri ve Fizik Öğrenme Stilleri, İstanbul.

Durukan, E. (2013). Türkçe öğretmen adaylarının öğrenme stilleri ve öğrenme stratejileri arasındaki ilişki. Electronic Turkish Studies, 8(1), 1307- 1319.

Ekici, G. (2013). Gregorc \& Kolb öğrenme stili modellerine göre öğretmen adaylarının öğrenme stillerinin cinsiyet ve genel akademik başarı açısından incelenmesi. Education \& Science/Egitim ve Bilim, 38(167).

Erden, M. \& Altun, S. (2006). Öğrenme Stilleri. İstanbul: Morpa Yayınları

Ergün, M. \& diğgerleri (1999). Öğretmenlik Mesleğine Giriş. Ankara: Ocak Yayınları.

Felder, R. M. (1996). Matters of Styles. ASEE Prism, 6 (4), 18-23. http://www.ncsu.edu/felderpublic/ Papers/LS-Prism.htm adresinden 19.10.2018 tarihinde alınmıştır.

Felder, R. M. \& Henriques E. R. (1995). Learning and Teaching Styles in Foreign and Secon Language Education. Foreing Language Annals, 28, 1, 21-31. http://www.ncsu.edu/felderpublic/ Papers/FLAnnals.pdf adresinden 19.10.2018 tarihinde alınmıştır.

Güven, M. (2004). Öğrenme Stilleri ile Öğrenme Stratejileri Arasındaki İlişki. Yayınlanmış Doktora Tezi. Anadolu Üniversitesi, Eskişehir.

Kaf Hasırcı, Ö. (2006). Sınıf öğretmenliği öğrencilerinin öğrenme stilleri: Çukurova Üniversitesi örneği. Eğitimde Kuram ve Uygulama Dergisi, 2(1), 15-25.

McCarthy, B. (2000). About teaching 4mat in the classroom. Wauconda, IL: About Learning.

Numanoğlu, G. \& Şen, B. (2007). Bilgisayar ve öğretim teknolojileri eğitimi bölümü öğrencilerinin öğrenme stilleri. Ahi Evran Üniversitesi Kırşehir Eğitim Fakültesi Dergisi, 8(2), 129-148.

Oral, B. (2003). Ortaöğretim öğrencilerinin öğrenme stillerinin incelenmesi. Kuram ve Uygulamada Ĕ̆itim Yönetimi, 35, 418-435.

Oral, B. \& Avanoğlu, Y. (2011). Öğrenme Öğretme Kuram ve Yaklaşımları, Öğrenme Stilleri ve Öğrenme Stili Modelleri. (Ed.) Behçet Oral. Ankara: Pegem Akademi Yayınları.

Senemoğlu, N. (2013) Gelişim, Öğrenme ve Öğretim Kuramdan Uygulamaya, 23. Baskı, Ankara: Yarg1 Yayınevi. 
Tepehan, T. (2004). Deniz Harp Okulu 1. Sinı Öğrencilerinin Mezun Oldukları Lise ve Lisans Ders Grupları İle Öğrenme Stilleri ve Akademik Başarıları Arasındaki İlişki. Yayınlanmamış Yüksek Lisans Tezi. Yıldız Teknik Üniversitesi Sosyal Bilimler Enstitüsü, İstanbul.

Veznedaroğlu, R. L. \& Özgür, A. O. (2005). Öğrenme stilleri: tanımlamalar, modeller ve işlevleri. İllköğretim-Online, 4(2), 1-16.

Yenen, E. T. \& Dursun, F. (2018). Öğretmen adaylarının ideal eğitim ortamına yönelik bakış açılarının incelenmesi. Anemon Muş Alparslan Üniversitesi Sosyal Bilimler Dergisi, 6(6) 1041-1049.

Yıldırım, A. \& Şimşek, H. (2011). Sosyal bilimlerde nitel araştırma yöntemleri. Ankara: Seçkin yayıncilik. 